\title{
Processing and nutrient quality evaluation of defatted soy
} \section{meat}

\author{
Md. Anisur Rahman Mazumder*, Hasin Akhlaq Brinto, Palash Chakrabortty and Anjuman Ara Begum \\ Department of Food Technology and Rural Industries, Bangladesh Agricultural University, Mymensingh- 2202, Bangladesh
}

\begin{abstract}
Defatted soy meat prepared from raw soybean is a very good source of protein and minerals. However, the presence of anti-nutritional factors affects its protein quality and limits the bioavailability of the other nutrients. The effect of soaking and blanching on the lipoxygenase, urease and trypsin inhibitor activity was investigated. Soaking at $65^{\circ} \mathrm{C}$ for $2 \mathrm{~h}$ and blanching at $100^{\circ} \mathrm{C}$ for $10 \mathrm{~min}$ significantly reduced the lipoxygenase, urease activity and more than $80 \%$ trypsin inhibitor was deactivated. Soy meat obtained from soaking at $65^{\circ} \mathrm{C}$ for $2 \mathrm{~h}$ and blanching at $100^{\circ} \mathrm{C}$ for $10 \mathrm{~min}$ showed the highest protein solubility than soaking at $60^{\circ} \mathrm{C}$ for $2 \mathrm{~h}$ and blanching at $100^{\circ} \mathrm{C}$ for $10 \mathrm{~min}(\mathrm{p}<0.5)$. Defatted soy meat processing with the help of soaking at $65^{\circ} \mathrm{C}$ for $2 \mathrm{~h}$ and blanching at $100^{\circ} \mathrm{C}$ for 10 min contained $9.0 \pm 1.0 \%$ moisture, $67 \pm 2.0 \%$ protein, $1.5 \pm 0.05 \%$ ash, and $45.0 \pm 2.5 \mathrm{mg}$ genistein per $100 \mathrm{~g}$ of soy meat.
\end{abstract}

\section{Introduction}

Soybean is one of the most economical and valuable agricultural commodities due to its unique chemical composition. Among cereal and other legumes, soybean contained the highest protein content around $40 \%$ (dry basis) and the second highest (20\%) oil content among all legumes, after peanuts. $70 \%$ of total soy proteins are glycinin and $\beta$-conglycinin [1]. Soy protein are highly digestible after proper heat treatment. However, soy protein is not an ideal protein due to its deficiency in the essential amino acid methionine. Soy contains methionine for only $1.39 \mathrm{~g} / 16 \mathrm{~g}$ of $\mathrm{N}$; while the recommendation by the Food and Agricultural Organization (FAO) is $3.5 \mathrm{~g} / 16 \mathrm{~g}$ of $\mathrm{N}$ $[2,3]$. Protein-bound methionine from some plants is poorly utilized, presumably because of poor digestibility [4]. Other components in the soybean includes varying concentration of isoflavone; high levels of minerals including iron, calcium, zinc; vitamins including a-tocopherol, niacin, pyridoxine and folacin [5]. Soy products has advantages in preventing heart disease, obesity, blood cholesterol, cancer, diabetes, kidney disease, osteoporosis, and blood pressure regulation [1,6,7]. Consumption of $25 \mathrm{~g} /$ day of soy protein significantly decreased triglycerides, total cholesterol and low-density lipoprotein (LDL) cholesterol [8]. Soy products are very good source of phenolic compounds with high antioxidant properties; such as isoflavones, a group of phytoestrogens that have been reported to possibly lower the risk of hormonal and age-related diseases. Among isoflavones, genistein is a powerful inhibitor of tyrosine carry additional small molecular modifiers, such as kinase activity in vitro [9] more importantly, genistein could act as an anti-oxidant and anti-browning agents in vivo and in vitro [10]. However, the presence of natural anti-nutrients, such as trypsin inhibitors (TI), lectins, phytic acids and indigestible oligosaccharides, has limited soybean and its products consumption.

Despite the high nutritional value of soybean and soy products, there are many compounds in the soybean that could interfere with protein quality including protease inhibitors, phytic acid and lipoxygenase enzymes [11]. The presence of protease inhibitors, Kunitztrupsin inhibitor (KTI) and Browman-Birk inhibitor of chymotrypsin (BBI) results the reduction in protein digestibility thus limiting the availability of essential amino acids such as trypsin $[12,13]$. Phytic acid might decrease the bioavailability of proteins by binding to peptides and amino acids thereby inhibiting proteolytic enzyme action [14]. Moreover, lipoxygenases catalyze lipid hydro-peroxidation leading to the so-called beany flavor thus limiting the consumption of soybean products [11]. It is very much necessary to inactive or destroy the anti-nutritive factors of soy bean and soy products.

World population is nearly 7 billion demands for huge amount of food supply with proper nutrient. Diet based on plant could partially address the problem of food crisis and animal protein malnutrition in several developing countries. Plant proteins provide desirable functional properties, such as solubility, viscosity. In the diet of developed countries, significant reduction in meat consumption $(>40 \%)$ is possible without risk of lack of micro -nutrients normally supplied through meat products. Therefore, a new alternative forms of food products and room for development of an attractive market around plant protein-based products in food industry is needed $[15,16]$. Soybeans might be transforming into different verities of soy foods to provide high nutrition and easily digestible products. Soybeans could be processed to produce a textured products and appearance similar to many other foods. For example, soybeans are the primary ingredient in many dairy product substitutes such as soy milk, margarine, soy ice cream, soy yogurt, soy cheese and meat alternatives (e.g. veggie burgers, soy meat). The research aimed to process defatted soy meat and evaluate the nutrient content of the soy meat.

${ }^{\star}$ Correspondence to: Md. Anisur Rahman Mazumder, Department of Food Technology and Rural Industries, Faculty of Agricultural Engineering and Technology, Bangladesh Agricultural University, Mymensingh- 2202, Bangladesh, Tel: 8801754146914; Fax: +8809161510; E-mail: anis_engg@bau.edu.bd

Key words: soy meat, lipoxygenase, trypsin inhibitor, protein solubility, genistein

Received: June 28, 2018; Accepted: July 23, 2018; Published: July 26, 2018 


\section{Materials and methods}

\section{Materials}

Whole soybean was purchased from local market (Mymensingh) and trypsin, D, L-BApNA, calcium chloride was purchased from Mitali Scientific Stores, Bangladesh.

\section{Soy meat processing}

Whole soybean was treated for inactivation or destruction of antinutritive factors. Soybean was soaked hot water $\left(60,65^{\circ} \mathrm{C}\right)$ for $2 \mathrm{~h}$ with $0.5 \% \mathrm{NaHCO}_{3}$ in water bath. The ratio of water and soybean for soaking was 2:1. The soybean was then de-hulled by using auto-dehulling machine. After removing the hull and other foreign materials form soybean, it was blanched for $10 \mathrm{~min}$ with addition of $0.5 \% \mathrm{NaHCO}_{3}$ at the temperature of $100^{\circ} \mathrm{C}$. The ratio of water and soybean was $2: 1$. Soybean was washed with potable water and crushed by using grinder. The crushed sample was defatted by solvent extraction method. Soy meat concentrate was prepared and extruded in to desirable size and shape.

\section{Determination of lipooxygenase (LOX) assays}

$100 \mathrm{~g}$ of samples were blended in $150 \mathrm{ml}$ of water at $4^{\circ} \mathrm{C}$ for $10 \mathrm{~min}$. The slurry was filtered through multi-layer cheese cloth (3 layers). The filtrate was centrifuged at $25000 \mathrm{x} g$ for $20 \mathrm{~min}$ at room temperature. The supernatant was used for the crude enzyme extract. LOX activity was measured as the change in absorbance at $234 \mathrm{~nm}$ with a linolenic acid substrate solution according to Gokmen et al. [17]. A double beam spectrophotometer (Photolab 7600UV-VIS) and $1 \mathrm{~cm}$ path-length cuvette were used for enzyme measurement.

\section{Determination of urease activity}

The urease activity was carried out by assay method describe by Croston et al. [18]. To prevent a decrease in urease activity with increasing alkalinity $\mathrm{pH} 6.8$ was maintained for urease-urea reaction. The reactions were carried out at temperature at $35 \pm 2^{\circ} \mathrm{C}$. The reagents used were $0.1 \mathrm{~N} \mathrm{HCl}, 0.1 \mathrm{~N} \mathrm{NaOH}$, phosphate buffer of $\mathrm{pH} 6.8$ made up of 0.025 mole of $\mathrm{K}_{2} \mathrm{HPO}_{4}, 0.025$ mole $\mathrm{KH}_{2} \mathrm{PO}_{4}$ and $0.8 \mathrm{~g}$ of glutathione per liter, and buffered urea solution was prepared daily by dissolving $6 \mathrm{~g}$ urea in $100 \mathrm{ml}$ of buffer solution without the glutathione.

Urease activity was determined by the method describes by Nowshin et al. [19]. $100 \mathrm{~g}$ of samples were blended in $150 \mathrm{ml}$ of water at $4^{\circ} \mathrm{C}$ for $10 \mathrm{~min}$. The slurry was filtered through multi-layer cheese cloth (3 layers). The filtrate was centrifuged at $25000 \mathrm{x} g$ for $20 \mathrm{~min}$ at room temperature. The supernatant was used for the urease activity of soy meat. Forty milliliters $(40 \mathrm{ml})$ of soy meat supernatant was added to $10 \mathrm{ml}$ of the buffer solution containing glutathione and was allowed to stand for $30 \mathrm{~min}$ at $40^{\circ} \mathrm{C}$. Ten milliliter $(10 \mathrm{ml})$ of the buffered urea solution was then added to initiate the reaction. The $\mathrm{pH}$ of the reaction was maintained 6.8 by adding $0.1 \mathrm{~N} \mathrm{HCl}$ slowly and using bromthymol blue in its green color range to indicate the desired end point. After $30 \mathrm{~min}$, the reaction was terminated by adding additional $0.1 \mathrm{~N} \mathrm{HCl}$ to a total of $10 \mathrm{ml}$. The system was then titrated $0.1 \mathrm{~N} \mathrm{NaOH}$ to $\mathrm{pH}$ 4.7. Similarly, a control was run parallel with each sample. The urease was inactivated by adding $\mathrm{HCl}$ to the sample before adding phosphate buffer and buffered urea solution. The difference between the control and sample in $\mathrm{ml}$ of $0.1 \mathrm{~N} \mathrm{HCl}$ or its ammonia equivalent was taken as the urease activity of the meal.

\section{Determination of phytate activity}

Phytate was extract for $60 \mathrm{~min}$ in a $20 \mathrm{ml}$ vial with $0.5 \mathrm{~N} \mathrm{HCl}$ in a ratio of 1:20 (w/v) while stirring. $50 \mathrm{mg}$ of soy meat and $10 \mathrm{ml}$ of 0.5 $\mathrm{N} \mathrm{HCl}$ was used throughout. Two milliliters $(2 \mathrm{ml})$ of soy meat extract was centrifuged at $18,000 \times g$ for $10 \mathrm{~min}$ in a micro-centrifuge. One milliliter $(1 \mathrm{ml})$ of supernatant containing phytate was then filtered with a $1 \mathrm{ml}$ tuberculin syringe and a $13-\mathrm{mm} / 0.45-\mu \mathrm{m}$ syringe filter. Filtered samples could be stored at $4^{\circ} \mathrm{C}$ for several days prior to HPLC analysis.

Phytate was determined by the modified method as described by Rounds and Nielsen [20]. Aliquot of phytate for HPLC analysis was achieved by using a 30-min linear gradient of $0.01 \mathrm{M} 1$-methylpiperazine at $\mathrm{pH} 4.0$ and $0.5 \mathrm{M} \mathrm{NaNO}_{3}$ in $0.01 \mathrm{M} \mathrm{1-methylpiperazine} \mathrm{at} \mathrm{pH} 4.0$ with a flow rate of $1 \mathrm{ml} / \mathrm{min}$. Wade's color reagent consisting of $0.015 \%$ $(\mathrm{w} / \mathrm{v}) \mathrm{FeCl}_{3}$ and $0.15 \%(\mathrm{w} / \mathrm{v}) 5$-sulfosalicylic acid was prepared based on Wade and Morgan [21] having a flow rate of $1 \mathrm{ml} / \mathrm{min}$. Phytate eluted from the column were mixed with Wade's reagents in a mixing tee with inline check valves for both eluents installed prior to the mixing tee to prevent backflow. The postcolumn reaction was allowed to take place in $0.05 \times 210 \mathrm{~cm}$ polyetheretherketone tubing at a combined flow rate of $2 \mathrm{ml} / \mathrm{min}$. The absorbance was monitored at $500 \mathrm{~nm}$ and the detector signals and/or phytate peaks were processed and integrated by chromatographic data acquisition system.

\section{Determination of trypsin inhibitor}

Trypsin inhibitor activity was determined according to the modified method described by Erlanger et al. [22]. $50 \mathrm{mg}$ of defatted soy meat and $5 \mathrm{ml}$ of $0.1 \mathrm{M}$ Tris- $\mathrm{HCl}$ buffer were mixed together to adjust $\mathrm{pH}$ 8.2. The solution was homogenized in an Erlenmeyer containing $20 \mathrm{mM}$ $\mathrm{CaCl}_{2}$ and agitated for $3 \mathrm{~h}$ followed by centrifugation for $3600 \mathrm{x}$ for 20 minutes. $100 \mathrm{ml}$ of soy meat extract were added with $450 \mu \mathrm{l}$ of buffer and $50 \mu \mathrm{l}$ of trypsin solution in a test tube and homogenized followed by keeping the suspension at room temperature for 10 minutes. 500 $\mu \mathrm{l}$ of the homogenate were transferred to a new test tube containing $500 \mu \mathrm{l}$ of buffer and $500 \mu \mathrm{l}$ of the D, L-BApNA solution. The solution was agitated for few minutes and left at room temperature for 10 minutes; the reaction was stopped by the addition of $300 \mu \mathrm{L}$ of $60 \%$ acetic acid. Absorbance of the solution was determined at $410 \mathrm{~nm}$ using a spectrophotometer (Photolab 7600UV-VIS) and the results were converted in $\mathrm{mg}$ of inhibited trypsin per gram of total protein in the sample.

\section{Determination of nutrient content of soy meat}

\section{Moisture content}

Moisture content was determined adopting AOAC [23] method. Moisture content was determined by placing an accurately weighed known amount sample in a pre-weighted porcelain crucible in an electric oven at $105^{\circ} \mathrm{C}$ for $24 \mathrm{hrs}$. After drying, crucible was removed from the oven and cooled in desiccator. It was then weight with cover glass. Drying cooling and weighting were repeated until constant weight was obtained. The loss of moisture was calculated as present moisture. The formula is mentioned bellow

$$
\% \text { of Moisture }=\left(w_{1}-w_{2}\right) / w_{1} \ldots \ldots \ldots \ldots \ldots . . . . . \text { equation (i) }
$$

Here, $W_{1}=$ Crucible + Sample weight $(\mathrm{g}) ; W_{2}=$ Crucible + Dry sample weight $(\mathrm{g})$

\section{Ash content}

Ash content was determined using AOAC [23] method. The accepted method was as follows: five-gram $(5 \mathrm{~g})$ moisture free samples 
were taken in porcelain crucible and pre-ash at $100^{\circ} \mathrm{C}$ in a gas burner. The sample was allowed to burn slowly and carefully avoiding any loss of sample with flame because the burning is necessary to avoid the lass of sample into a muffle furnace under high temperature. The crucibles were then placed in a muffle furnace and heated at $550^{\circ} \mathrm{C}$ for $6 \mathrm{hrs}$. The crucibles were then cooled in a desiccator. The average weight in percentage of each sample of the remaining material was taken as ash.

Ash content $(\%)=(w 2-w 0) /(w 1-w 0) \times 100$. equation (ii)

Here, $w_{0}=$ weight of empty crucible; $w_{1}=$ weight of empty crucible + sample and $w_{2}=$ weight of empty crucible + sample (after drying)

\section{Protein content}

Protein content was determined using AOAC [23] method. The accepted method was as follows:

One-gram (1 g) sample was weighted and transferred into the digestion flask. About $25 \mathrm{ml}$ of concentrated $\mathrm{H}_{2} \mathrm{SO}_{4}$ and $5 \mathrm{~g}$ of digestion mixture was added to the flask. The concepts of the Kjeldahl flask was heated over a low flame in a digestion chamber until the solution became clear (bluish color). After digestion, the flask was cooled carefully, and $100 \mathrm{ml}$ volume was made with distilled water. An aliquot $(5 \mathrm{ml})$ was taken for distillation in a distillation flask. In a $100 \mathrm{ml}$ conical flask, $10 \mathrm{ml}$ boric acid solution, $10 \mathrm{ml}$ ammonia free water and 2 drops of mixed indicator was taken in Kjeldahl. The distillation apparatus was connected with a delivery tube dipping below the boric acid solution in the conical flask. To the distillation flask, about $10 \mathrm{ml}$ of $40 \% \mathrm{NaOH}$ solution was added and the ammonia was distilled off into the boric acid solution. When the distillation was over (usually $100 \mathrm{ml}$ is collected), the burner was removed, the condenser and delivery tube was washed down into the receiver. The collected ammonia is titrated with $0.1 \mathrm{~N}$ $\mathrm{HCl}$ solution and titre volume is recorded. The nitrogen value thus obtained were converted to total crude protein by multiplying with a factor of 6.25. The formula mentioned below:

$\%$ Nitrogen $=[($ Titre value-Blank titre $) \times$ Nof $\mathrm{HCl} \times 14 \times$ Volume made] / [Aliquot taken for estimation $\times$ Sample taken $\times 1000$ ] $\times 100 \ldots . .$. equation (iii)

$\%$ Protein $=\%$ Nitrogen $\times 6.25$

\section{Determination of genistein by HPLC method}

Extraction of genistein: Extraction of genistein from food stuffs and their qualification and quantification were performed as previously reported [24], with some modification. Samples $(5 \mathrm{~g})$ were extracted with $50 \mathrm{ml}$ of $80 \%$ methanol by sonication for $30 \mathrm{~min}$ at $45^{\circ} \mathrm{C}$. These extract solutions were centrifuged at $2500 \times \mathrm{g}$ for $20 \mathrm{~min}$ and the supernatants were evaporated to dryness using a centrivap evaporator. The dried extracts were dissolved in $5 \mathrm{ml}$ of $50 \%$ methanol. Liquidliquid extraction by 3 times of $20 \mathrm{ml}$ of $\mathrm{n}$-hexane was carried out to remove lipids form the samples. After evaporation of the aqueous methanol phase, the residue was dissolved in $2.5 \mathrm{ml}$ of $80 \%$ methanol, and an aliquot was filtered through $0.2 \mu \mathrm{m}$ membrane filter before analysis by HPLC.

HPLC analysis for genistein: Acetonitrile and trifluoroacetc acid were filtered separately through $0.45 \mu \mathrm{m}$ PTFE and de-gassed in an ultrasonic bath for $30 \mathrm{~min}$ before use. Six standard concentrations of pure ( $\geq 98 \%)$ genistein were prepared at the concentration of $0.1 \mu \mathrm{g} / \mathrm{g}, 1$ $\mu \mathrm{g} / \mathrm{g}, 5 \mu \mathrm{g} / \mathrm{g}, 10 \mu \mathrm{g} / \mathrm{g}, 20 \mu \mathrm{g} / \mathrm{g}$ and $40 \mu \mathrm{g} / \mathrm{g}$ in $99.9 \%$ ethanol. Twenty $\mu \mathrm{l}$ samples were injected into an analytical octa decyl silane (ODS) column $(5 \mu \mathrm{m}$ particle size, $4.6 \times 250 \mathrm{~mm}$ ) and a mobile phase of a gradient of 0
$-60 \%$ acetonitrile in $0.1 \%$ trifluoroacetic acid was pumped in at a flow rate of $1.2 \mathrm{ml} / \mathrm{min}$ at $25^{\circ} \mathrm{C}$. Genistein was monitored by UV absorbance at $262 \mathrm{~nm}$. The contents of genistein were estimated from standard curves. For genistein, the retention time was $60 \mathrm{~min}$.

\section{Determination of protein solubility of soy meat}

Protein solubility of soy meat was determined based on nitrogen (N) solubility [25]. One hundred-gram (100 g) soy meat was centrifuged at $10,000 \times g$ for $10 \mathrm{~min}$ at room temperature to separate solid and liquid. The suspension was pipetted and $\mathrm{N}$ solubility was determined by using Lowry method [26]. Protein solution $(0.3 \mathrm{ml})$ was added in test tubes with $0.3 \mathrm{ml} 2 \mathrm{M} \mathrm{NaOH}$. The solution was heated at $100^{\circ} \mathrm{C}$ for $10 \mathrm{~min}$ and cooled at room temperature $\left(25^{\circ} \mathrm{C}\right)$. Three milliliters $(3 \mathrm{ml})$ of complex forming agent ( $2 \%$ sodium carbonate, $1 \%$ copper sulphate and $2 \%$ sodium potassium tartarate) was added to the solution. The solution was then mixed well. This solution was incubated at room temperature for $10 \mathrm{~min}$. Then $0.3 \mathrm{ml}$ of Folin-Ciocalteau solution (reagent solution) was added to each tube and incubated for $30 \mathrm{~min}$ (not more than 60 min). Absorbance of the solution was determined at $550 \mathrm{~nm}$ using a spectrophotometer (Photolab 7600UV-VIS). The absorbance was plotted against protein concentration to get a standard calibration curve and calculate percent nitrogen solubility (Figure 1).

\section{Results and discussion}

\section{Effect of soaking and blanching on lipoxygenase (LOX) activity}

The residual activity of LOX during soaking of soybean at different soaking conditions was shown in Figure 2. Soaking of soybean at $60^{\circ} \mathrm{C}$ for $2 \mathrm{~h}$ showed around $80 \%$ reduction of LOX activities. Very rapid inactivation was investigated in soybean LOX at $65^{\circ} \mathrm{C}$ for $2 \mathrm{~h}$. As full (100\%) LOX activity reduction was achieved by $65^{\circ} \mathrm{C}$ for $2 \mathrm{~h}$, the effects of blanching studies did not continue for LOX activity. The result suggested that soaking at $65^{\circ} \mathrm{C}$ for $2 \mathrm{~h}$ was sufficient to reduce $100 \%$ LOX activity. Nonetheless, $60^{\circ} \mathrm{C}$ could reduce $90 \%$ LOX activity within

\section{Whole Soybean \\ $\downarrow$ \\ Washing of soybean}

\section{$\checkmark$}

Soaking in $0.5 \% \mathrm{NaHCO}_{3}$ at $55^{\circ} \mathrm{C}$ and $60^{\circ} \mathrm{C}$ for $2 \mathrm{~h}$, soybean : water $=1: 2$

Dehulling of soybean

$\checkmark$

Blanching at 80,90 and $110^{\circ} \mathrm{C}$ in $0.5 \% \mathrm{NaHCO}_{3}$ for $10 \mathrm{~min}$, Soybean : water $=1: 2$

$$
\checkmark
$$

Bean crushing and grinding

$\checkmark$

Fat extraction using $\mathrm{n}$-hexene

$\checkmark$

Defatted flakes

$\downarrow$

Prepare soy meat concentrate

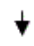

Extrusion to various size and shape

Figure 1. Preparation of soy meat 


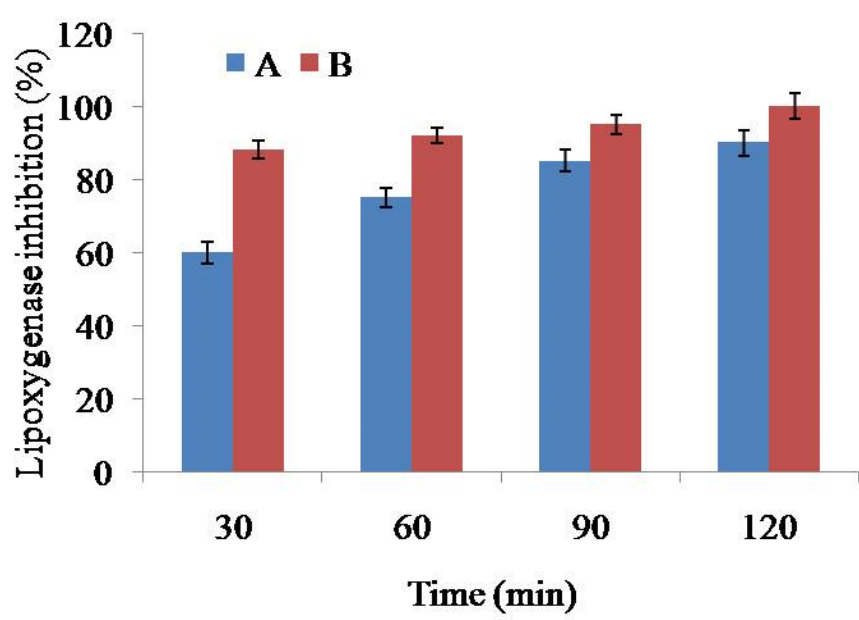

Figure 2. Effect of soaking temperature on lipoxygenase activity in soy meat. Bars represent standard deviation. $\mathrm{A}=$ Soybean soaking at $60^{\circ} \mathrm{C}$ temperature for $2 \mathrm{~h}$. B=Soybean soaking at $65^{\circ} \mathrm{C}$ temperature for $2 \mathrm{~h}$

first $10 \mathrm{~min}$, and the residual activity remained relatively stable during further $20 \mathrm{~min}$.

More than $90 \%$ of LOX activity was recommended for optimum quality of vegetable during frozen storage [19]. However, processing of defatted soy meat requires $100 \%$ inhibition of LOX activity since soybean contained lot of anti-nutritional factors such as saponins, phospholipids, protease inhibitors, phytates and trypsin inhibitors [27]. Hence, blanching is an obvious pre-treatment during processing of soy meat.

\section{Effect of soaking and blanching on phytate content}

Soaking at $65^{\circ} \mathrm{C}$ for $2 \mathrm{~h}$ showed only $25 \%$ reduction of phytate activity though it is significantly $(\mathrm{p}>0.5)$ different with that at $60^{\circ} \mathrm{C}$ for 2 $\mathrm{h}$ (Figure 3). The result suggested for further heat treatment (blanching) of soybean before processing of defatted soy meat. Combination of soaking, and blanching $\left(100^{\circ} \mathrm{C}\right.$ for $\left.10 \mathrm{~min}\right)$ showed rapid inactivation of soybean phytate. Maximum amount $(85 \%)$ of phytate was reduced with combination of soaking $\left(65^{\circ} \mathrm{C}\right.$ for $\left.2 \mathrm{~h}\right)$, and blanching $\left(100^{\circ} \mathrm{C}\right.$ for $10 \mathrm{~min})$.

Maximum of the anti-nutrients in the beans and legumes are found in the skin. Many of the anti-nutrients are water-soluble and simply dissolve when soaked in water [28]. In legumes and beans, soaking has been reduced minimum amount of phytate, protease inhibitors, lectins, tannins and calcium oxalate. As for example, $12 \mathrm{~h}$ soaking reduced the phytate content of peas by up to $9 \%$ [29]. As a result, combination of both soaking and blanching could reduce maximum amount of phytate. It is very much essential to reduce phytate in soy food because phytate inhibits calcium absorption. It reduces iron, zinc, magnesium and calcium absorption and resulted in poor iron absorption in soy foods [10,30]. Reduction of around $90 \%$ phytate activity will help to absorb calcium content of soy meat.

\section{Effect of soaking and blanching on urease activity}

Urease activity of the raw soybean was significantly higher $(\mathrm{p}<0.5)$ than that of the soaked soybean at 60 and $65^{\circ} \mathrm{C}$ for $2 \mathrm{~h}$. Soaking at $65^{\circ} \mathrm{C}$ for $2 \mathrm{~h}$ showed maximum $50 \%$ reduction of urease activity significantly different with $60^{\circ} \mathrm{C}$ for $2 \mathrm{~h}$ (Figure 4). The result suggested that soaking $65^{\circ} \mathrm{C}$ for $2 \mathrm{~h}$ were not sufficient to destroy $100 \%$ urease activity; further heat treatment was necessary to inactivate urease activity. Blanching $\left(100^{\circ} \mathrm{C}\right.$ for $\left.10 \mathrm{~min}\right)$ and soaking at $65^{\circ} \mathrm{C}$ for $2 \mathrm{~h}$ could significantly reduce $100 \%$ urease activity. Heat treatment was adequate to reduce urease activity that might be a good indicator of trypsin inhibition.

\section{Effect of soaking and blanching on trypsin inhibitor}

Soy meat processing through soaking at $65^{\circ} \mathrm{C}$ for $2 \mathrm{~h}$, blanching at $100^{\circ} \mathrm{C}$ for $10 \mathrm{~min}$ significantly reduced more trypsin inhibitor than soy meat prepares by soaking at $60^{\circ} \mathrm{C}$ for $2 \mathrm{~h}$ and blanching at $100^{\circ} \mathrm{C}$ for 10 min. However, blanching at $100^{\circ} \mathrm{C}$ for $10 \mathrm{~min}$ for complete destruction or inactivation of trypsin inhibitor. The result suggested that steam blanching rather than hot water blanching might be more effective for soy meat. Heat treatment at $150^{\circ} \mathrm{C}$ for $30 \mathrm{~min}$ for raw soybean before soy meat will completely destroy trypsin inhibitor. Trypsin inhibitors could be reduced to desirable levels after autoclaving the soybeans at $120^{\circ} \mathrm{C}$ for 18 minutes and $121^{\circ} \mathrm{C}$ for 10 minutes, respectively [31,32] (Figure 5).

\section{Effect of soaking and blanching on protein solubility of soy meat}

The protein solubility of soy meat was increased rather than raw soybean $\left(75 \%\right.$ solubility). Soaking temperature $\left(65^{\circ} \mathrm{C}\right.$ for $\left.2 \mathrm{~h}\right)$ increased minimum increased minimum amount of protein solubility (maximum

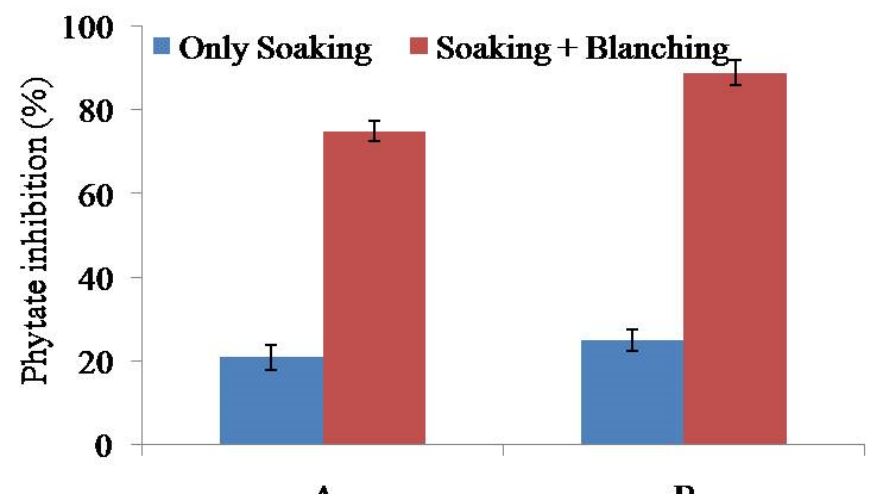

$\mathbf{A}$

B

Soaking temperature

Figure 3. Combined effect of soaking temperature and blanching $\left(100^{\circ} \mathrm{C}\right.$ for $\left.10 \mathrm{~min}\right)$ on the phytate activity in soy meat. A=Soaking temperature $60^{\circ} \mathrm{C}$ for $2 \mathrm{~h}$. B=Soaking temperature $65^{\circ} \mathrm{C}$ for $2 \mathrm{~h}$. Bars represent standard deviation

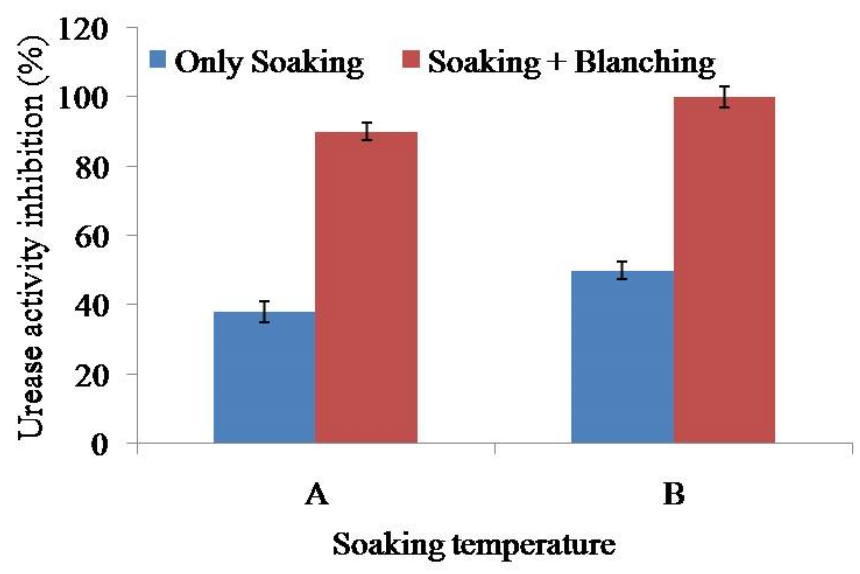

Figure 4. Combined effect of soaking temperature and blanching $\left(100^{\circ} \mathrm{C}\right.$ for $\left.10 \mathrm{~min}\right)$ on the urease activity in soy meat. $\mathrm{A}=$ Soaking temperature $60^{\circ} \mathrm{C}$ for $2 \mathrm{~h}$. B=Soaking temperature $65^{\circ} \mathrm{C}$ for $2 \mathrm{~h}$. Bars represent standard deviation 
$12 \%$ increase at $65^{\circ} \mathrm{C} 2 \mathrm{~h}$ soaking) suggested that blanching is necessary to increase the protein solubility. However, it is suggested that soaking temperature increasing increased the protein solubility. Soaking temperature $65^{\circ} \mathrm{C}$ for $2 \mathrm{~h}$ and blanching at $100^{\circ} \mathrm{C}$ for $10 \mathrm{~min}$ increased significant amount of protein solubility. This might be due to denaturation of soy protein during high temperature blanching though amino acid content did not change at this temperature [33] (Figure 6).

\section{Nutrient content of defatted soy meat}

Soaking of raw soybeans in chemical solutions such as sodiumbi-carbonate and/or sodium hydroxide had a significant effect on the chemical composition and reduction in beany flavor in soy products $[19,34]$. However, sodium carbonate and sodium hydroxide had a significant effect on the reduction in beany flavor in soy milk [27]. For the analysis of nutrient content of soy meat, soybean treatment was selected based on soaking and blanching temperature. Soybean treated at $65^{\circ} \mathrm{C}$ for $10 \mathrm{~min}$ (soaking) and $100^{\circ} \mathrm{C}$ for $2 \mathrm{~h}$ (blanching) for analysis of soy meat. Defatted soy meat contained moisture $9.0 \pm 1.0 \%$, protein $67.0 \pm 2.0 \%$, ash $1.5 .0 \pm 0.05 \%$, and $45.0 \pm 2.5 \mathrm{mg}$ genistein per $100 \mathrm{~g}$ of soy meat. Protein content might be reduced as protein recovery started to

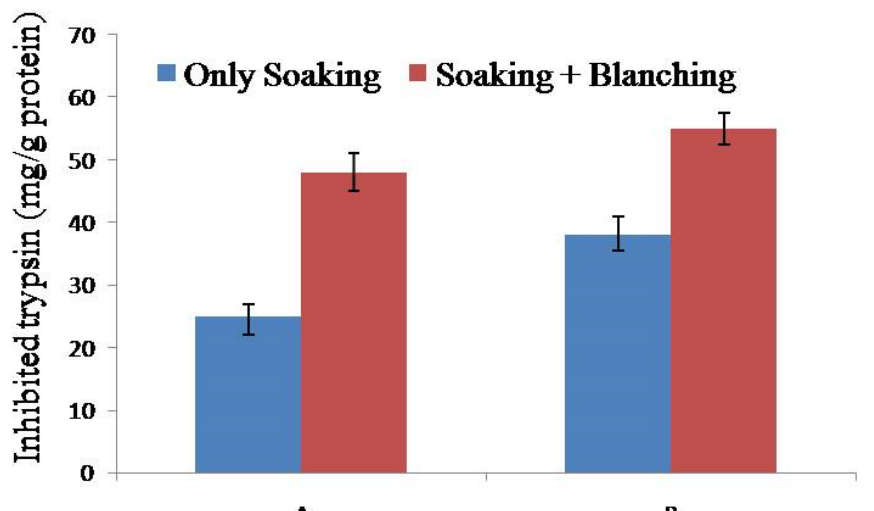

A

\section{Soaking temperature}

Figure 5. Combined effect of soaking temperature and blanching $\left(100^{\circ} \mathrm{C}\right.$ for $\left.10 \mathrm{~min}\right)$ on the trypsin inhibition activity in soy meat. $\mathrm{A}=$ Soaking temperature $60^{\circ} \mathrm{C}$ for $2 \mathrm{~h} . \mathrm{B}=$ Soaking temperature $65^{\circ} \mathrm{C}$ for $2 \mathrm{~h}$. Bars represent standard deviation

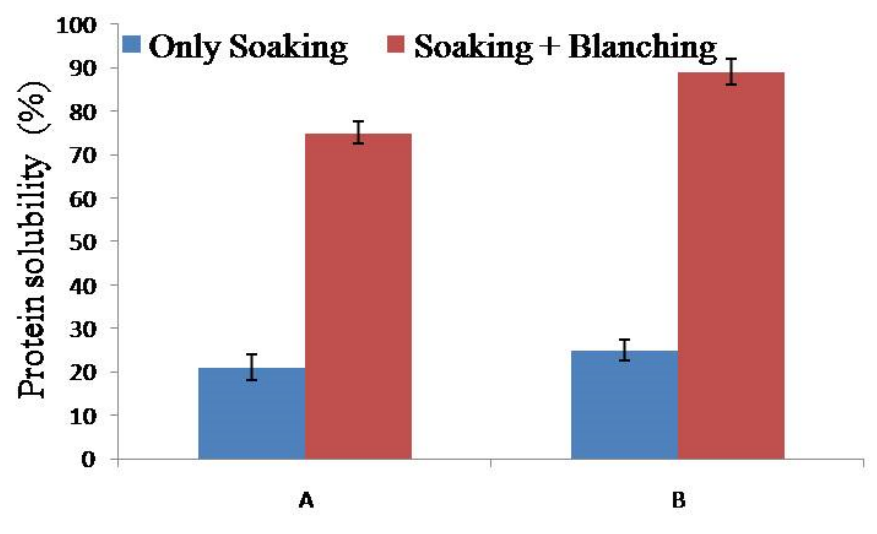

\section{Soaking temperature}

Figure 6. Combined effect of soaking temperature and blanching $\left(100^{\circ} \mathrm{C}\right.$ for $\left.10 \mathrm{~min}\right)$ on the protein solubility of soy meat. $\mathrm{A}=$ Soaking temperature $60^{\circ} \mathrm{C}$ for $2 \mathrm{~h} . \mathrm{B}=$ Soaking temperature $65^{\circ} \mathrm{C}$ for $2 \mathrm{~h}$. Bars represent standard deviation decreased slightly at more than $70^{\circ} \mathrm{C}$. With high blanching temperature above $70^{\circ} \mathrm{C}$, there was an indication that the insoluble carbohydrate fraction, with hydroscopic and swelling properties, might significantly contribute to inhibition of filtration and cause losses in the solid yield of soy meat [19]. Increasing blanching temperature to $100^{\circ} \mathrm{C}$ could not increase the solid content of soy meat due to fixation of matrix at high temperature. Blanching at high temperature $\left(100^{\circ} \mathrm{C}\right)$ denatured soy protein and increased the water holding capacity of soybean, extraction of protein was dramatically reduced after denaturation and matrix formation [35-37].

\section{Conclusion}

Soy meat contained high amount of protein and ash content. However, soaking temperature and high blanching temperature effect the nutrient and anti-nutrient content of soy meat. Blanching temperature affect the both nutrient and anti-nutrient content of soy meat. High temperature $\left(100^{\circ} \mathrm{C}\right)$ is sufficient to reduce $100 \%$ of lipooxygenase, urease activity and maximum amount of phytate and trypsin inhibitor but reduce the protein content of soy meat as well as genistein content of soy meat.

\section{References}

1. Liu K (1997) Soybeans: chemistry, technology and utilization. New York: Chapman and Hall.

2. Friedman M (1996) Nutritional value of food proteins from different food sources. $J$ Agric Food Chem 44: 6-29.

3. Friedman M, Brandon DL (2001) Nutritional and health benefits of soy proteins. $J$ Agric Food Chem 49: 1069-1086. [Crossref]

4. Begbie R, Pusztai A (1989) The resistance to proteolytic breakdown of some plant (seed) proteins and their effects on nutrient utilization and gut metabolism. In: Friedman, M. (ed) Absorption and Utilization of Amino Acids. CRC: Boca Raton. Pp: 243-263.

5. Mazumder MAR, Hongsprabhas P (2016a) A review on nutrient quality of soymilk powder for malnourished population. Pakistan Journal of Nutrition 15: 600-606.

6. Garcia MC, Torre M, Marina ML, Laborda F (1997) Composition and characterization of soyabean and related products. Crit Rev Food Sci Nutr 37: 361-391. [Crossref]

7. Riaz MN (1999) Soybeans as functional foods. Cereal Food World 44: 88-92.

8. Adlercreutz CH, Goldin BR, Gorbach SL, Höckerstedt KA, Watanabe S, et al. (1995) Soybean phytoestrogen intake and cancer risk. J Nutr 125: 757S-770S. [Crossref]

9. Akiyama T, Ishida J, Nakagawa S, Ogawara H, Watanabe S, et al. (1987) Genistein, a specific inhibitor of tyrosine-specific protein kinases. J Biol Chem 262: 5592-5595. [Crossref]

10. Rahman Mazumder MA, Hongsprabhas P (2016) Genistein as antioxidant and antibrowning agents in in vivo and in vitro: A review. Biomed Pharmacother 82: 379392. [Crossref]

11. Esteves EA, Martino HSD, Oliveira FCE, Costa NMB (2010) Chemical composition of a soybean cultivar lacking lipoxygenases (LOX2 and LOX3). Food Chem 122: 238242 .

12. Dia VP, Gomez T, Vernaza G, Berhow M, Chang YK, et al. (2012) Bowman-Birk and Kunitz protease inhibitors among anti-nutrients and bio-actives modified by germination and hydrolysis in Brazilian soybean cultivar BRS 133. J Agric Food Chem 60: 7886-7894.

13. Monteiro MRP, Costa NMB, Oliveira MG, de A Pires CV, Moreira MA (2004) Qualidadeproteica de linhagens de soja com ausência do Inibidor de TripsinaKunitz e das isoenzimasLipoxigenases. Revista de Nutrição 17: 195-205.

14. Deak NA, Johnson LA (2007) Fate of phytic acid in producing soy protein ingredients $J$ Am Oil Chem Soc 84: 369-376.

15. Boye J, Zare F, Pletch A (2010) Pulse protein: processing, characterization, functional properties and applications in food and feed. Food Res Int 43: 414-431.

16. Rodrigues IM, Coelho JFJ, Carvvalho MGVS (2012) Isolation and valorisation of vegetable proteins from oilseed plants: methods, limitations and potential. J Food Eng 109: 337-346. 
17. Gokmen V, Bahceci S, Acar J (2002) Characterization of crude lipoxygenase extract from green pea using modified spectrophotometric method. Eur Food Res Technol 215 $42-45$.

18. Croston CB, Smith AK, Cowan JC (1955) Measurement of urease activity in soybean meal. J Am Oil Chem Soc 32: 279-282.

19. Nowshin H. Devnath K, Begum AA, Mazumder MAR (2018) Effect of soaking and grinding conditions on anti-nutrient and nutrient contents of soy milk. Journal of Bangladesh Agricultural University 16: 158-163.

20. Rounds MA, Nielsen SS (1993) Anion-exchange high-performance liquid chromatography with post-column detection for the analysis of phytic acid and other inositol phosphates. J Chromatogr A 653: 148-152. [Crossref]

21. Wade HE, Morgan DM (1955) Fractionation of phosphates by paper ionophoresis and chromatography. Biochem J 60: 264-270. [Crossref]

22. Erlanger BF, Kokowsky N, Cohen W (1961) The preparation and properties of two new chromogenic substrates of trypsin. Arch Biochem Biophys 95: 271-278. [Crossref]

23. AOAC (2000) Official Methods of Analysis of AOAC International, 16th Ed, 5th rev. Method 930.15. Association of Official Chemists, Gaithersburg, MD.

24. Coward L, Barnes NC, Setchell KDR, Barnes S (1993) Genistein anddaidzein, and their b-glycoside conjugates: anti-tumor isoflavones in soybeanfoods from American and Asian diets. J Agric Food Chem 41: 1961-1967.

25. Mazumder MAR (2016) The roles of genistein as anti-browning agent in liquid and powdered emulsions. PhD thesis. Graduate School, Kasetsart University, Bangkok, Thailand.

26. Lowry OH, Rosebrough NJ, Farr AL, Randall RJ (1951) Protein measurement with the Folin phenol reagent. J Biol Chem 193: 265-275. [Crossref]

27. Giri SK, Mangaraj S (2012) Processing influences on composition and quality attributes of soymilk and its powder. Food Eng Rev 4: 149-164.
28. Fernandes AC, Nishida W, Costa Proença RPDa (2010) Influence of soaking on the nutritional quality of common beans (Phaseolus vulgaris L.) cooked with or without the soaking water: a review. Int J Food Sci Technol 45: 2209-2218.

29. Bishnoi S, Khetarpaul N, Yadav RK (1994) Effect of domestic processing and cooking methods on phytic acid and polyphenol contents of pea cultivars (Pisumsativum) Plan Food for Human. Nutrition 45: 381-388.

30. Schlemmer U, Frølich W, Prieto RM, Grases F (2009) Phytate in foods and significance for humans: food sources, intake, processing, bioavailability, protective role and analysis. Mol Nutr Food Res 53: S330-S375. [Crossref]

31. Machado FPP, Queiróz JH, Oliveira MGA, Piovesan ND, Peluzio MCG, et al. (2008) Effects of heating on protein quality of soybean flour devoid of Kunitz inhibitor and lectin. Food Chem 107: 649-655.

32. Mendes FQ, Oliveira MGdeA, Cardoso LR, Costa NMB, Sant'ANA RdeCO (2007) Digestibilidadeproteica e caracterizaçãobromatológica de linhagens de soja com ausênciaoupresença do inibidor de tripsinaKunitz e das isozimaslipoxigenases. $J$ Biosci 23: $14-21$.

33. Kwok KC, Shiu YW, Yeung CH, Niranjan K (1998) Effect of thermal processing on available lysine, thiamine and riboflavin content in soymilk. $J$ Sci Food Agric 77: 473478

34. Khaleque A, Bannatyne WR, Wallace GM (1970) Studies on the processing and properties of soymilk. I. Effect of preprocessing conditions on the flavour and compositions of soymilks. J Sci Food Agric 21: 579-583. [Crossref]

35. American Oil Chemists' Society (AOCS) (2002) Tentative method Ba 9-58 - Urease activity. In: Smith, AK \& Circle, S.J. (eds) Soybeans: Chemistry and technology. Westport: AVI.

36. Krintiras GA, Göbel J, Bouwman WG, van der Goot AJ, Stefanidis GD (2014) On characterization of anisotropic plant protein structures. Food Funct 5: 3233-3240. [Crossref]

37. Ewan YWHA, Morr CV, Seo A (1992) Isoflavoneaglycone and volatile organic compounds in soybeans: Effects of soaking treatments. J Food Sci 57: 414-426.

Copyright: $(\mathrm{O} 2018$ Mazumder AR. This is an open-access article distributed under the terms of the Creative Commons Attribution License, which permits unrestricted use, distribution, and reproduction in any medium, provided the original author and source are credited. 